\title{
Access to Market of a Manufacturing Small Business Sector in Ghana
}

\author{
Mavis Serwah Benneh Mensah ${ }^{1}$ \\ ${ }^{1}$ School of Business, University of Cape Coast, Cape Coast, Ghana \\ Correspondence: Mavis Serwah Benneh Mensah, School of Business, University of Cape Coast, Cape Coast, \\ Ghana. Tel: 233-245-093-600. E-mail: mbenneh@yahoo.com
}

Received: February 24, 2012 Accepted: March 26, 2012 Online Published: June 16, 2012

doi:10.5539/ijbm.v7n12p36

URL: http://dx.doi.org/10.5539/ijbm.v7n12p36

\begin{abstract}
This paper concludes presentation on two most relevant binding constraints identified by a manufacturing 'small' business sector in Ghana. The first constraint of limited access to technology was discussed in an earlier paper in this Journal. The second constraint of limited access to market was studied to determine the extent to which manufacturing 'small' businesses had access to market and to identify one or two overriding factors that constrained ability of the businesses to access market. This was achieved through a survey of 85 manufacturing small businesses in Berekum District and Sunyani Municipality of Ghana. Low demand for goods came up as the overriding factor that constrained the enterprises' ability to access market. To tackle the problem of low demand, it is indispensable for government to spearhead creation of required co-ordination externalities and champion the course of self-discovery as a nation.
\end{abstract}

Keywords: market access, demand, low income, co-ordination externalities, self-discovery

\section{Introduction}

In Ghana, domestic enterprises in the private sector are at the forefront of economic activity while the public sector (with greater state participation) becomes less and less prominent. With the private sector as the main engine for growth, substantial and significant increases in private investments and entrepreneurship are imperative in attaining the much desired growth and development for poverty reduction. Access of enterprises to larger and profitable markets, therefore, becomes crucial.

Better access to larger markets, such as international markets for exports and investment, is one key factor in enabling economic growth. 'Policy makers and the development community realise the need not just for economic growth but for pro-poor growth which improves the living standards of the poor and their ability to exercise their basic human rights' (UNIDO, 2006). Consequently, policies that promote broad-based business growth incorporate micro and small enterprises into the pro-poor growth agenda. This approach is highly indispensable for the Ghanaian economy of which micro, small and medium-sized enterprises (MSMEs, herein also referred to as small businesses or the small business sector) form the backbone of the economy. It is estimated that small businesses contribute about 70 percent to Ghana's gross domestic product (GDP) and account for about 92 percent of businesses in the country. The sector also provides about 85 percent of manufacturing employment in Ghana (Abor \& Quartey, 2010).

Gaining access to international markets can be a strategic instrument for competitiveness and further development of SMEs. For example, enterprises that have access to the global market are able to tap opportunities such as new niche markets and exploit economies of scale, scope, volume and technological advantages. They are also able to upgrade their technological capability and afford improved access to finance (OECD, 2004). Accordingly, SMEs, that are internationally active, report higher turnover and higher employment growth (European Commission, 2010).

Moreover, improving market access for developing countries is an inevitable requirement for growth in these countries and an imperative to supporting medium-term global growth ("Annex: Summing Up", 2005). Consequently, various entities have established mechanisms for championing better access of goods and services from developing countries onto the international market. Examples are the World Trade Organisation (WTO), North-South arrangements such as the Economic Partnership Agreement (EPA) and African Growth and Opportunity Act (AGOA). The Economic Community of West African States (ECOWAS) and the South African Development Corridor (SADAC) are some examples of such trade arrangements in Sub-Sahara Africa (SSA). 
These trade arrangements notwithstanding, Ghana's access to the international market is very low. For instance, Ghana's already low export had been declining between 2004 and 2008, except for 2005 (The International Monetary Fund, 2011; The International Monetary Fund, 2007). However, from 2009 to date, Ghana's exports of goods and services, as a percentage of GDP, saw some improvements although the improvements have not been entirely consistent (The International Monetary Fund, 2011). More so, the improvement is largely due to oil discovery and export which began in 2010; a condition which has inflated Ghana's GDP per capita, making it a (lower) middle income country since 2011. Furthermore, Ghana is classified as a low foreign direct investment (FDI) potential country and even worse, an under-performer in attracting FDI (UNCTAD, 2006).

As a result, governments have over the years sought to enhance the small business sector's access to the international market through the institution of several policies. For instance, the Ghana MSME Project 2006-2013 seeks to enhance access of micro, small and medium-sized enterprises (MSMEs) to both the domestic and international markets as one of the key priorities. A major challenge is that the limited access of the MSMEs has been attributed to several factors for policy attention.

However, it has been established that policies achieve little or nothing at all when policy makers are presented with 'a laundry list of needed reforms and have either tried to fix all of the problems at once or started with reforms that were not crucial at given times to the country's growth potential. In such a situation, reforms, more often than not, have gotten in each other's way, with reform in one area creating unanticipated distortions in another area' (Hausmann, Rodrik \& Velasco, 2006, p. 13). Consequently, this study was conducted in Berekum District and Sunyani Municipality in Ghana as a case and premise to learn about the generally perceived limited access of MSMEs to market and inform policy on the one or two underlying reason(s) for the prevailing situation.

To guide the study towards the attainment of its objective, there are a number of research questions. (a) To what extent do enterprises in the study region have access to market in terms of their ability to reach sales target and target customers? (b) Do enterprises face constraints in their bid to access market? (c) What is (are) the most pressing factor(s) that constrains enterprises from having access to market? The paper, including the introduction, is divided into five sections. The next section is a review of literature on the nature of the small business sector's access to market and barriers to its ability to access market globally and nationally. This is followed by methodology, presentation of results, discussion, and conclusions and policy implications respectively.

\section{Literature Review}

This section of the paper provides review of literature on the nature of the small business sector's access to market and factors that limit the sector's ability to access market.

\subsection{The Nature of Small Business Sector's Access to Market}

Globally, although small and medium-sized enterprises (SMEs) make up over 90 percent of businesses and typically account for 50 percent of gross domestic product (GDP) and 60 percent of employment, they generate 30 percent of exports and attract an even smaller proportion of FDI (UNIDO, 2006). Thus, worldwide, SMEs make significant contributions to GDP and employment generation. However, relatively few SMEs engage in international business activities such as exporting, importing and foreign direct investment.

A survey of 9,480 SMEs on the internationalisation of European SMEs, conducted by the European Commission in 2009 in 33 European countries, buttress the point that SMEs are underrepresented in international business. According to the survey, a considerable number of European SMEs are engaged in international activities, yet only a small percentage is involved in internationalisation beyond the internal market (European Commission, 2010). In Sub-Sahara Africa (SSA) and within economic blocs in SSA, internationalisation beyond the internal market is very limited for all business sizes. Export and import data on SSA shows that there is little economic activity among countries in SSA, and in terms of export, between SSA and the rest of the world (The International Monetary Fund, 2007).

In developing and least developed countries, SMEs are more significant in numbers and employment, yet they are less likely to be successful exporters (UNIDO, 2006). Literature indicates that Ghana is no exception. In Ghana, it is estimated that SMEs contribute about 70 percent to the country's GDP, account for about 92 percent of businesses and provide about 85 percent of manufacturing employment (Abor \& Quartey, 2010). However, it is believed that SMEs contribute an insignificant percentage to Ghana's low exports which averaged 24.1 percent of GDP from 2004 to 2008, 29.3 percent for 2009 and 2008, and (a projection of) 38.4 percent for 2011 and 2012 (The International Monetary Fund, 2011). As of 1994, it was reported that only 1.7 percent of firms exported their output (Kayanula \& Quartey, 2000). 
In sum, SMEs at the global and national levels make significant contributions to employment and wealth creation. However, they have limited access to market, especially the international market; this is much more pronounced in developing and least developed countries.

\subsection{Barriers to the Small Business Sector's Access to Market}

Globally, several reasons have been cited for SMEs limited access to market. A report by the Organisation for Economic Co-operation and Development (OECD), in 2004, identifies a number of barriers to SMEs access to international markets. These include intellectual property (IP) rights; political risks; corruption and rule of law issues. It was also noted that SMEs are less well-equipped than larger firms to address these difficulties (OECD, 2004).

In a survey of 9,480 SMEs in 33 European countries conducted by the European Commission in 2009, the most important barriers to internationalisation as perceived by the SMEs are price of their own products and the high cost of internationalisation (internal barriers); lack of capital, lack of adequate information, and lack of adequate public support and the costs or difficulties with paper work associated with transport (external barriers). Internal and external barriers are closely related. The bigger the enterprise's resources, the easier it is to deal with external barriers (European Commission, 2010) as also reported by the OECD in its special report on SMEs access to market (OECD, 2004).

Over the years, research has shown that export activity is indeed linked to rapid growth of enterprises - not as the end result but rather as its starting point. However, certain forms of international trade could be barriers in themselves. For instance, in spite of the several benefits that responsible trade offers to participating firms and nations, it is clear that it can be a barrier to international markets and, in particular, may impact disproportionately on SMEs. It is argued that if 'responsible trade standards are indeed overtly protectionist or simply complicated, or disproportionately expensive' in their monitoring requirements, they could prevent developing country SMEs from gaining the market access so crucial to their growth and contribution to economic development and poverty reduction (UNIDO, 2006). Although basic social and environmental standards are already part of the competitive landscape for SMEs in some sectors, meeting these standards will be a necessary but not a sufficient condition for market access. In addition, meeting technical, quality, safety and other demands of key buyers such as major brands and retailers is often crucial to securing market access (UNIDO, 2006).

In its analysis of data on SME market access and internationalisation from 20 Asia Pacific Economic Co-operation (APEC) economies, the policy support unit of the APEC indicates that barriers to SMEs access to international markets can be characterised as being contingent and dynamic. It is, therefore, important to understand the nature of the SME and its stage of international operations, and the corresponding barriers to internationalisation for the SME. The results of a joint OECD-APEC survey indicate that both policy makers and SMEs indicated shortage of working capital to finance exports; identifying foreign business opportunities; limited information to locate/analyse markets; and inability to contact potential overseas customers as four barriers among the six most serious impediments to SME access to international markets. This shows that problems which are internal to the firm (e.g. capabilities) rather than external factors (e.g. business environment) were deemed to be the main barriers to internationalization (APEC, 2010).

Limited trade among countries in SSA have been attributed to several factors such as factor immobility, intense competition from imports, under-developed ICT sector and poor transportation network on the continent. A recent addition to the list of factors is the implications of the concept of divergence and convergence of trade benefits. It has been discovered that regional integration between rich countries alone or poor countries alone produces divergence instead of convergence. The logic is that regional integration between rich or poor countries benefit member countries that have characteristics closest to the global average. Therefore, trade between only poor countries implies the relatively rich countries will benefit from trade due to whatever advantage, such as technological capability, they have at hand (see Collier, 2007). Consequently, it is not that profitable for many countries in SSA to trade among themselves since a majority is classified as poor. Otherwise, the relatively richer countries will be benefiting from trade at the expense of the relatively poorer countries.

Similarly, in a special study conducted by the WTO on trade, income disparity and poverty, it was found that trade makes significant contributions towards economic growth and potentially faster poverty alleviation, particularly, for countries that are lagging behind their trade partners. In addition, countries that trade extensively with one another tend to exhibit a higher incidence of income convergence than other countries. The relatively poorer liberalising countries and their wealthier trade partners are able to move to higher and steeper growth paths (The WTO, 1999). 
At the national front, the picture does not look much different. Limited access to market is one of the major challenges facing many African countries such as Ghana, Kenya, and Tanzania. At the macro level, unfavourable national policies are the key constraints to SME access to market. In a policy position paper on SMEs market access through private and public procurement and linkages, it was indicated that in Tanzania, limited market access, lack of financial access, and poor technology are among the biggest challenges facing the SME sector. Factors that limit SMEs market access in public and private procurement include uncompetitiveness, stringent government procurement rules, corruption, inadequate business linkage facility and limited access to information (Confederation of Tanzania Industries, 2009). Kufour (2008) in a paper on employment generation and SME development points out that Ghana has a relatively small domestic market and hence provides little scope for the growth of firms beyond a certain point.

In establishing a link between trade liberalisation and poverty, it is a fact that trade reform can in the long-run create and destroy markets with varying degrees of implications for poverty reduction. Evidence seems to indicate that trade liberalisation is generally a positive contributor to poverty alleviation - it allows people to exploit their productive potential, assists economic growth, curtails arbitrary policy interventions and helps to insulate against shocks (WTO, 1999). Trade liberalisaiton offers SMEs advantages of scale, and access to new technologies and market niches. These notwithstanding, it brings risks, which SMEs may be less equipped to deal with than larger enterprises. Even for firms not geared towards export, greater trade liberalisation can cannibalise their local markets with cheaper imports (UNIDO, 2006).

At the micro level, firm-related factors are the major constraints to SME access to market. In a policy discussion paper on policy environment for promoting SMEs in Ghana and Malawi by Kayanula and Quartey (2000; see also IFC, 2010; Kufuor, 2008), it was established through content analysis that SMEs face a number of constraints. Some of the identified constraints include input constraints such as limited factor availability and cost, and high cost of obtaining local raw materials; credit constraint; lack of entrepreneurial and business management skills; difficulties in gaining access to appropriate technologies and information on available techniques; limited domestic demand exacerbated by inefficient distribution channels and limited access to public contracts and subcontracts arising from cumbersome bidding procedures and/or lack of information. These constraints were attributed to difficulty in absorbing large fixed costs, the absence of economies of scale and scope in key factors of production, and the higher unit cost of providing services to smaller firms.

With particular reference to Ghana, a content analysis of studies, on regulatory environment for promoting SMEs in Ghana and Malawi by Kayanula and Quartey (2000), indicates that demand constraints limited the growth of SMEs. Although Ghana operates under a liberalised trade regime, threat from international competition was not found by SMEs to be a major constraint on their activities. Accordingly, less than one percent of SMEs (mostly medium-sized enterprises) complained that there were too many imported substitutes coming into Ghana. Limited international marketing experience, poor quality control, product standardisation and little access to international partners (Aryeetey et al., 1994 as cited in Aryeetey \& Ahene, n.d.) have been mentioned as limiting export activities of small scale enterprises in Ghana.

The preceding review indicates that a multitude of factors account for the present limitation to SME market access at the national and international levels of business activity. In the face of resource scarcity, there is the need to identify, for the short-term, the one or two most relevant binding constraint(s) which when removed will bring about the much desired growth (Hausmann, Rodrik \& Velasco 2006).

\section{Methodology}

The study followed a combined research design; that is, the mixed methodology design (Creswell, 1994) comprising qualitative and quantitative studies. The research was carried out in Sunyani Municipality and Berekum District in the Brong Ahafo Region of Ghana. Ghana is classified as a low exporting country and an under-performer in attracting FDI (The International Monetary Fund, 2007; UNCTAD, 2006). Accordingly, the Ghanaian state has sought over the years to improve access of Ghanaian enterprises to both the domestic and international markets as spelt out in the Private Sector Development Strategy I and the MSME Project 2006-2013. With MSMEs forming a greater percentage of enterprises in the country, it is imperative to ascertain their access to market and any constraints thereof. The Brong Ahafo Region is considered ideal for the study in that it shares similar economic and social characteristics with the other regions in Ghana, except to some extent, the capital region, Greater Accra and the Northern Regions of Ghana.

The study population was made up of 227 private sector manufacturing MSMEs that were at least two years into operation and employing a minimum of two full-time workers. The age and employment 'limits' were essential in ensuring that enterprises had considerable business experience for a study of this nature. Due to unavailability 
of comprehensive data on the small business sector in Ghana, employment level has been the key distinguishing factor in defining business size. Consequently, definitions of business size by the National Board for Small Scale Industries (NBSSI) and by the Regional Project on Enterprise Development (RPED) in Ghana were adopted. Micro enterprises employ one to five people while small enterprises employ between six and 29 people. Medium-sized enterprises employ 30 to 99 people. The sampling frame was derived from the most recent national industrial census (2003-2004/2005) database secured from the Ghana Statistical Service and crosschecked with data compiled by the researcher in October 2006.

The study sample was 95 which represented 34 percent of the study population. Respondents were selected through proportionate stratified sampling in the following order - first, on the basis of the two study locations (Sunyani Municipality and Berekum District) to arrive at sample size for each location; second, by manufacturing sub-sectors (wood, metal, textile, structural, and soap and related products) in each study location to arrive at sample size for each sub-sector; and third, by random selection of respondents in each sub-sector. Respondents comprised enterprise owner-managers, and hired managers where management was not in the hands of the owner.

Questionnaire method was used to collect data. This was buttressed with interviews where certain questionnaire responses demanded further elaborations. It is globally acknowledged that 'it is difficult, if not impossible, at times to have access to SME data due to unavailability' (APEC, 2010). This was the case of the MSMEs surveyed. Consequently, variables were measured subjectively. Two variables were used to measure access to market. These are sales performance and (geographic) market coverage. Once an entrepreneur indicates attainment or non-attainment of sales target, it is further enquired whether, on such basis, the business did well or not on a five-point scale taking into consideration a previous response on whether an 'overambitious' target was set. Entrepreneurs' perception of business performance and market coverage for the coming year was also sought.

Thus, the main indicators for measuring sales performance were ability to meet previous year's sales target, the entrepreneur's rating of that performance and expected performance (sales) for the coming year. As observed by Watson (2003), '...due primarily to data limitations, previous studies have normally limited their assessment of performance to output measures such as sales or profit (or growth in sales or profit)...'. In line with this, Massey, Auld, Lewis, Perry, Walker and Warriner (2005), in a study of business excellence of 50 New Zealand micro enterprises, found out that among the several indicators used to measure performance, majority of the firms better associated with turnover/growing the firm and profitability. The indicator for market coverage was how wide the product(s) of an enterprise is geographically marketed locally, nationally and internationally. The main constraints to the enterprise's ability to achieve sales target and wider market coverage were also assessed.

Descriptive statistics (percentages and in few instances, mean scores) were used to analyse data. SPSS 14 was used for the data analysis. To arrive at the most relevant binding constraint(s), a decision tree by Hausmann, Rodrik and Velasco (2006) together with their recommended new approach to economic reform was adopted for analysing the research findings. Hausmann, Rodrik and Velasco (2006) used the decision tree in their recommended 'new approach to economic reform' to identify the relevant binding constraints that countries, like Brazil and El Salvador, needed to work on to bring about the much desired growth. The recommended approach to economic reform is based on the argument that 'by focusing on the one or two areas that represent the biggest hurdle to growth, countries will be more likely to achieve success from their reform efforts' rather than trying to fix all of the problems at once or losing focus as a result of being presented with a multitude of constraints such that countries started with reforms that were not crucial to their growth potential' (Hausmann, Rodrik \& Velasco, 2006). Besides, reforms in most instances have gotten in each other's way, with reform in one area creating unanticipated distortions in another area.

\section{Results and Discussion}

On the whole, the manufacturing MSMEs surveyed were young with a mean age of 13 years. They operated in six manufacturing sub-sectors. These included wood, food processing, textile, metal, structural, and chemical (soap and related products) sub-sectors. Employment level stood at a maximum of 29 employees and a minimum of one employee with 80 percent of enterprises falling into the micro enterprise category.

\subsection{Access to Market}

Manufacturing MSME's access to market was measured in terms of the enterprise's ability to achieve sales target the previous year and the extent of geographic market coverage. On the whole, 54 percent of the MSMEs (see Figure 1) performed below expectation in the previous year. That is, they did not achieve sales target and reported varied performances of fair, poor and very poor. One percent of MSMEs were not certain of their 
performance, mainly, because they did not set targets the previous year. The remaining 45 percent reported satisfactory performance of well and very well.

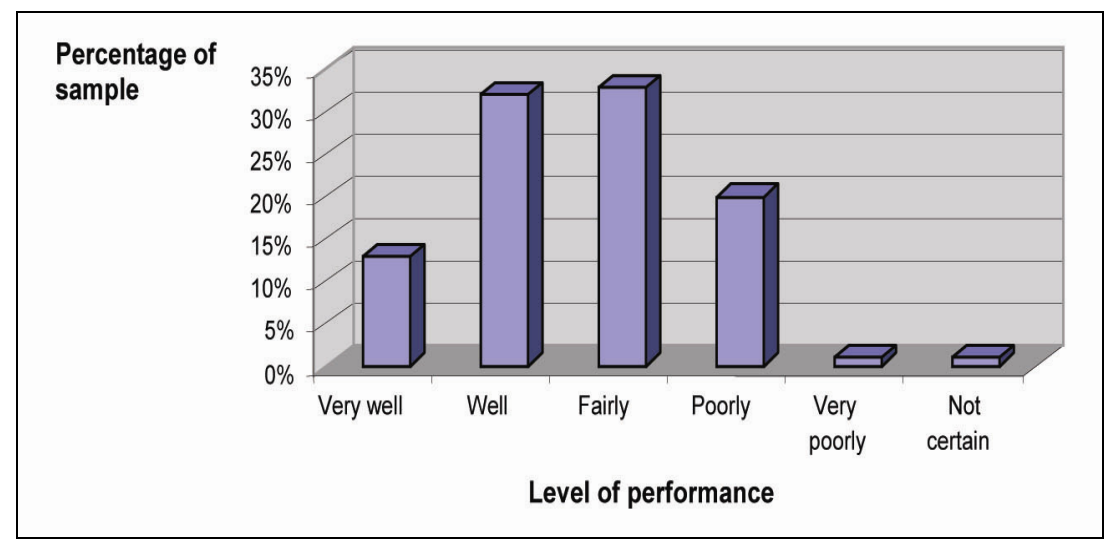

Figure 1. Previous Sales Performance

Source: Fieldwork

In terms of geographic market coverage, 64 percent of the MSMEs had customer base limited to the Brong Ahafo Region, that is, they did not access markets in the other nine regions of Ghana. Out of this percentage, 32 percent had customer base limited to Berekum Township and Sunyani Township, while five percent had customer base extending to other towns in Berekum District and Sunyani Municipality. The remaining 27 percent had customer base extending to other districts in the Brong Ahafo Region. A cursory look at Figure 2 brings to mind the wider perspective of entrepreneurs in search of customers. That is, majority of entrepreneurs who looked beyond the town for customers went beyond the municipality or district to other regions in Ghana. Correspondingly, 32 percent of the MSMEs had customer base extending to other regions in Ghana, while four percent had customers on the international market.

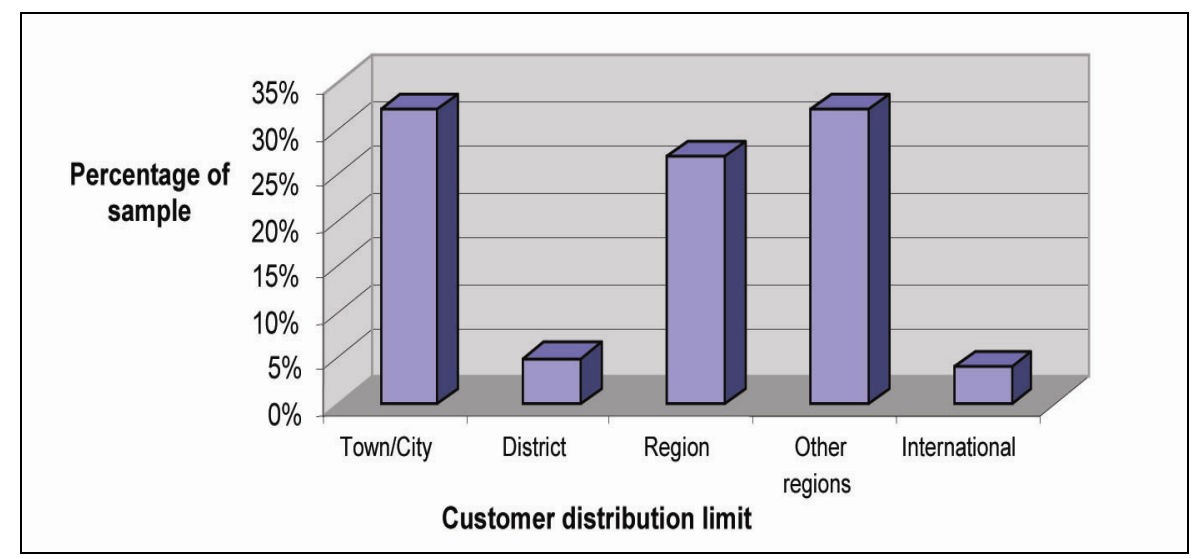

Figure 2. Current Customer Distribution/Location

Source: Fieldwork

The study also sought entrepreneurs' views on expected future sales performance and customer base considering economic conditions in Ghana, especially the local business climate at the time. The future looked relatively better with 69 percent of enterprises expecting to perform well or very well in the coming year; this indicates an expected rise of 24 percent over the previous year's total of 45 percent. However, sixteen percent of enterprises surveyed were not certain about the coming year and could not tell with certainty whether sales will increase or decrease or will remain the same (see Figure 3). 


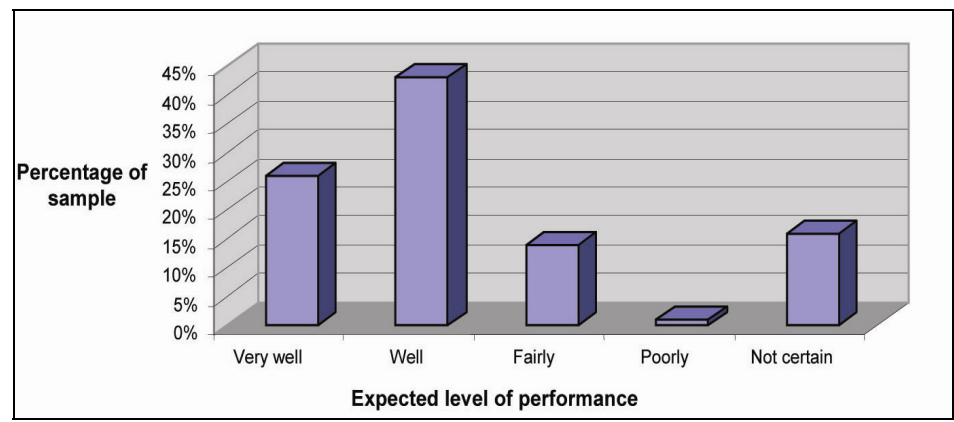

Source: Fieldwork

Figure 3. Future Sales Performance

In terms of expected change in customer base the coming year (Figure 4), 20 percent of entrepreneurs were not certain of what their customer base would be. Fifty four percent of entrepreneurs expected an increase in customer base the coming year, while 15 and 11 percent expected a decrease and no change in their customer base respectively.

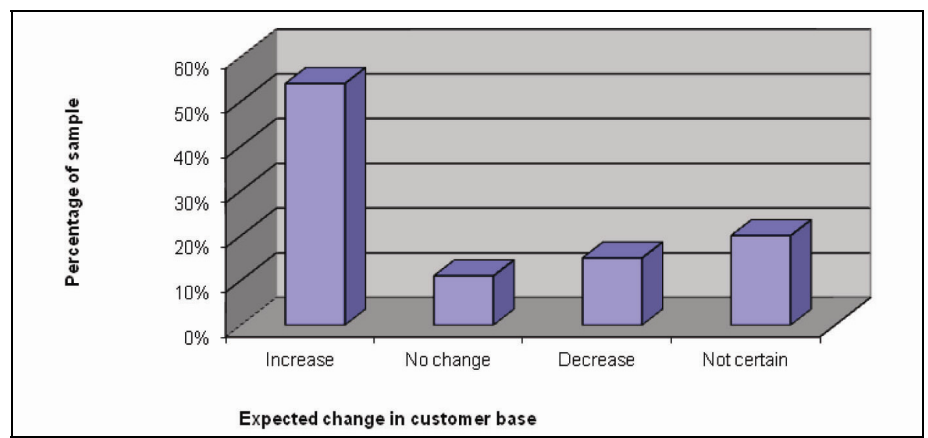

Figure 4. Future Customer Distribution/Location

Source: Fieldwork

\subsection{Constraints to Accessing Market}

MSMEs that performed below expectation in terms of achieving sales and customer targets gave insight into reasons behind the 'failure'. Identified constraints were categorised into demand constraints, production-related constraints, competition constraints and risk of growing large.

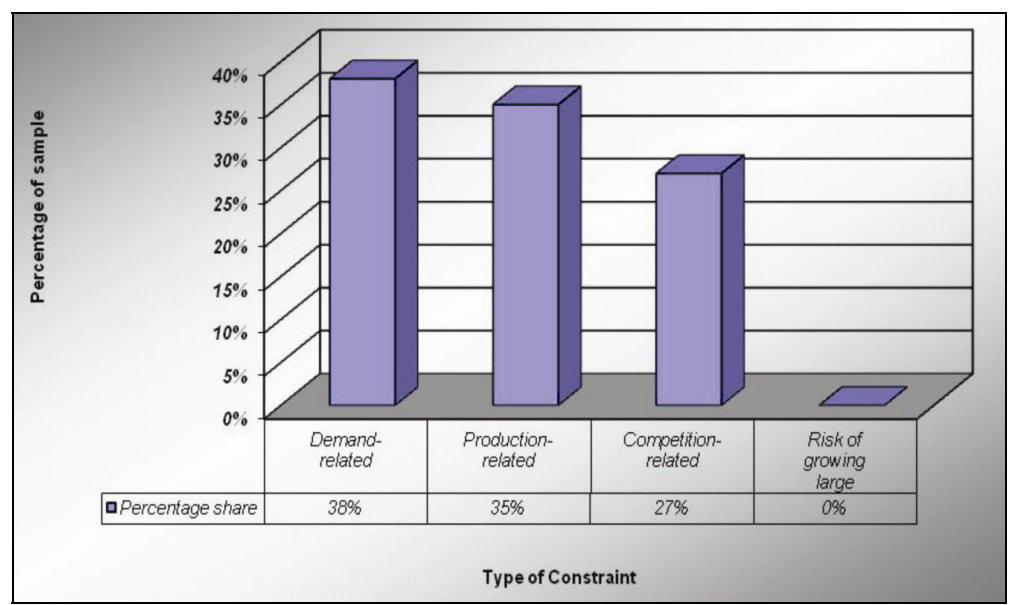

Figure 5. Constraints to Accessing Market

Source: Fieldwork 
Demand and production-related constraints were quite closely ranked after each other. Thirty eight and 35 percent of respondents respectively cited them as key constraints to their ability to access market (see Figure 5). Demand as a constraint implies low demand for goods. Entrepreneurs explained, through interview, that the low demand for goods was a result of low purchasing power of their customers. Respondents clarified that customers complained of lack of money or weak financial ability which prevented them from demanding goods as wanted. Production-related constraints centred on two main issues. These were inadequate finance (both working capital and difficulty in securing funds from external sources) and lack of appropriate tools and machines for production.

Competition as a constraint hinged on availability of cheaper and/or quality substitutes on the market. Twenty seven percent of respondents considered competition-related factors as major constraint to access market. Their main concern was the saturation of the market with so many indigenous MSMEs competing against each other and, for the wood sub-sector, there was particular concern over emerging cheaper imports from Asia. However, risk of growing large was not cited as a key constraint.

From the results above, more than half of the MSMEs served markets in the Brong Ahafo Region (which accounts for less than 10 percent of the total population of Ghana), while four percent engaged in export activity. In terms of sales performance the previous year, less than half were able to meet their expectations. It can, therefore, be deduced that the enterprises surveyed had poor access to the national and international market. The overriding factor that accounted for the limited access to market was low demand followed by production-related constraints and competition respectively.

\subsection{Discussion}

The study findings show that almost all the manufacturing MSMEs surveyed had their activities limited to the national market. This buttresses findings of earlier studies which indicate that much of SME activity was limited to the national market with low representation on the international market (European Commission, 2010; The International Monetary Fund, 2007; UNIDO, 2006; Aryeetey et al., 1994 as cited in Aryeetey \& Ahene, n.d). Furthermore, low demand for goods emerged as the key constraint to ability of the enterprises to access larger markets. Similarly, studies by Kayanula and Quartey (2000), the IFC (2010) and Kufuor (2008) indicated low demand as the key constraint to SME access to market and growth, particularly in Ghana.

The MSMEs surveyed attributed the low demand to low purchasing power of customers. However, it is highly appealing to explain low demand as a competition problem since it is often argued that in a liberalised regime, poor quality and/or expensive locally made goods are eventually not able to stand competition from better imports. It is true that Ghana is flooded with many imports offered at relatively cheaper prices. Normally in the face of such fierce competition customers, as rational as they are, will purchase the most affordable and/ or quality products. Moreover, the Ghanaian market is small in size such that when large enterprises in Ghana and importers dominate the market with quality and affordable substitutes, small enterprises have little chance to survive.

However, there is little to show that the low demand experienced by the enterprises surveyed is a result of competition from better quality and cheaper substitutes from large local firms and imports. The reason is that majority of the MSMEs invest and specialise in production of differentiated products as well as products with less competition from large domestic firms and importers. For further elaborations on this, the study sample can be categorised into two. These are sub-sectors with strong indirect competition from products manufactured in Ghana by few large enterprises and imported products. The sub-sectors include food processing, textile and soap and related products. The second category comprises sub-sectors with scarce substitutes and limited competition from large enterprises and imports. The sub-sectors are wood, structural and metal sub-sectors.

Whereas the first group of sub-sectors had low demand as the overriding constraint, the second was mostly constrained by production-related factors. Competition facing the first group can be described as indirect because food processing activities such as production of palm (red cooking) oil and local alcoholic beverages, as well as manufacture of textile and soap and related products, mostly concentrate on meeting local demand for differentiated products that are not readily provided by the few large domestic enterprises or through imports.

On the other hand, for the second category of sub-sectors, it can be argued that when these sub-sectors are faced with strong competition from large domestic enterprises and imports, they will also have low demand as leading constraint. The answer depends on whether these enterprises have good access to what they currently miss for effective production to meet demand - finance and modern equipment. Yet, in the face of scarcity of these two, the presence of the enterprises in the market is very strong. This is basically explained by the fact that technological software, in terms of product design for this second category, meets the taste and preferences of 
consumers. Products are also offered at relatively reasonable prices. Another good reason is the small size of the Ghanaian market flooded with many indigenous manufacturing MSMEs. This makes these sub-sectors unattractive to large firms or foreign investors, especially where there is no justification for good returns on investment.

Moreover, with the exception of food processing and soap and related products, the main source of financing production, for all enterprises surveyed, is the customer. Thus, in the face of limited working capital and difficulty in obtaining external funds (as also established by Kufuor, 2008; Kayanula \& Quartey, 2000), a pre-finance system has evolved over the years such that customers have to pay at least the cost of production before an order is met. Consequently, low income and associated low purchasing power of customers have led to low demand for goods and hence inadequate finance to fund production. If competition from large domestic enterprises and imports was the underlying reason for low demand for goods, then the MSMEs should have been taken over due to a failing pre-finance system where customers would prefer already-made imports, and products from large domestic firms because of affordability and/or assured quality.

However, the MSMEs, to a greater extent, are still vibrant in the domestic market for their differentiated products and relatively better price offer. Thus, low demand for goods is, therefore, not a direct problem of competition from large domestic firms or imports. As reiterated by Kayanula and Quartey (2000), although Ghana operates under a liberalised trade regime, threat from international competition was not found by SMEs to be a major constraint on their activities.

Using a decision tree by Hausmann, Rodrik and Velasco (2006), it is observed that a major characteristic of a developing country like Ghana is low levels of private investments and entrepreneurship. For the past decades, insufficient increases in factors of production, particularly physical capital was thought to be the cause of low growth (Hausmann, Rodrik \& Velasco, 2006). In recent years, however, the focus of development cooperation is on increasing and upgrading physical infrastructure, improving governance and regulations, and human capital. The intriguing question is, can the problem of limited access to market be attributed to poor governance and institutions, low savings, low level of education, and/or inadequate physical infrastructure?

Ghana is a country with low savings and low investments. By 2007, the level of domestic savings had been averaging 6.8 percent of GDP annually since 1982. This has been attributed to low incomes (Aryeetey \& Baah-Boateng, 2007). Ironically, however, Ghana has very high lending rates and rewards domestic savings with low interest rates. Low investment in Ghana could also be attributed to distortions that keep private returns low. Main causes for insufficient reward for individual risk taking are high taxes, macroeconomic imbalances, weak contract enforcement and property rights, political uncertainty, poor physical infrastructure, labour policy, high cost of finance and the exchange rate. However, none of these are significant concerns as shown by the study findings and previous studies (example, Mensah, 2012).

In Ghana, education is relatively not well rewarded with a great pool of unemployed graduates adding up each year to the country's souring graduate unemployment rate of 44 percent in 2010 (Appiah-Kubi, 2011). Quality of education may be a part of the low growth story in Ghana but it is not a principal constraint. Under normal circumstance, in the face of scarcity of quality human resource, the few qualified professionals should be well rewarded through good wages and salaries, but this is not the case. Moreover, thousands of unemployed graduates from tertiary institutions are just counting their hopes to be squeezed into an already overstretched public sector or have the chance to travel abroad for better chances in life. The formal private sector is too small to absorb these graduates joining the market each year for job search. Limited demand for goods and services does not offer most enterprising graduates profitable entrepreneurial opportunities to join the already concentrated market.

The problem of low demand which limits MSMEs ability to access market and/or have good returns on economic activity can, therefore, be said to originate from the remaining two possible causes on the decision tree. These are failure of the market and the government to expand existing market and lack of self-discovery. That is, there is failure of the market as well as the government to facilitate the creation of a market system (co-ordination externalities) that offers the right incentives to boost local demand, and to attain significant and sustainable increases in regional and international trade. There is also a lack of self-discovery (lack of technological foresight), especially by the market in terms of its ability to develop competitive higher-productivity products as well as non-traditional products that can be produced profitably at the local level for export. In fact, coordination externalities and self-discovery are interrelated in this case.

Lack of self-discovery and failure to boost demand originate from low appropriability. Low appropriability is explained by over concentration of MSMEs (which constitute more than 90 percent of registered businesses in 
Ghana) on few economic activities. This is seen as a strategy of avoiding direct competition from large domestic firms and importers. Since demand is highly for basic necessities, small enterprises have to compete side by side to meet the limited demand. Hence, they are not able to advance effectively on the experience curve towards the production of higher-productivity products and hardly benefit from economies of scale and scope.

Furthermore, it is virtually unprofitable to venture into the production of luxuries or goods that are not basic necessities. Such goods will not receive good patronage not because the people choose to but for the basic reason that their purchasing power, resulting from low incomes, is so low that they cannot afford to. As pointed out by Nurkse in the early $1950 \mathrm{~s}$, "The trouble is due by no means solely to discontinuities in the technical forms of capital equipment, though these will accentuate it. It is due above all to the inevitable inelasticity of demands at low real-income levels. It is in this way that poverty cramps the inducement to invest and discourages the application of capital to any single line of production' (Nurkse 1953, pp. 9-10 as cited in Asche, 2006, p. 21). In effect, the second relevant binding constraint - production-related constraint - is a result of (the first) low demand for goods and services. The problem of low incomes of Ghanaians has also been raised by Aryeetey and Baah-Boateng (2007) who argue that reasonable economic growth in Ghana (recently attained lower middle income country status) has not yet resulted in structural change and adequate employment.

\section{Conclusions and Policy Implications}

The fundamental objectives of this paper were to determine the extent of manufacturing MSMEs' access to market and identify the primary factor(s) that constrains the enterprises' ability to access market. By using the case of manufacturing MSMEs in Berekum District and Sunyani Municipality of the Brong Ahafo Region, Ghana, two key findings emerged. First, more than 95 percent of the MSMEs surveyed had their activities limited to the national market, with a greater percentage thereof serving only the town of origin. Sales performance was also low. In effect, the enterprises had limited access to market. Second, low demand emerged the key factor that explains the limited access of the enterprises to market. The second identified key factor, production constraints, traces back to the issue of low demand.

Per analysis and discussion, the problem of low demand emanates from two fundamental issues. These are failure of the market and the government to expand existing market (inadequate co-ordination externalities), and lack of self-discovery as a nation. The inevitability of coordination externalities has been stressed in growth literature as a form of big push which governments can offer to their economies to bring them out of the so-called poverty trap.

There is, therefore, the need to boost local demand, especially for the study region, as a premise for tackling the problem of low demand; enhance business and technological support for enterprises; and champion deeper regional trade and better access to the global market. Boosting local demand may involve supporting the creation of more economically viable projects (self-discovery) and employment opportunities which, over time, are expected to raise the income, purchasing power and savings ability of individuals. In economic terms, the essence is to raise the income elasticity of demand of Ghanaians and provide a learning conduit for developing higher productivity products and non-traditional goods that can be profitably produced at the local level and compete on the global market. In pursuance of active international trade, it is imperative that enterprises and the government consider the implications of divergence and convergence of trade benefits when selecting trade partners.

The study findings support existing literature on access of MSMEs to market. Globally and nationally, it has been established that majority of MSMEs have their activities limited to the national market with little representation on the international market. A second contribution to literature is that, in a liberalised economy, limited access to a local and possibly national market does not always necessarily emanate from intense competition from imports. Limited access to market can result from inelasticity of demand at low income levels particularly notable of nations with small national markets and little international business activity.

A limitation of the study is that performance was subjectively measured through attainment or non-attainment of sales target (output measure) without relating it statistically to input and without controlling for differences in risk. This was so due to unavailability of required data, hence the need to follow the conventional means of assessing MSMEs' performance. In addition, the percentage of the study sample that engages in export activity is small. This may explain the absence of constraints, such as limited marketing international experience and poor quality control, identified by earlier studies on small scale enterprises that export in Ghana.

Notwithstanding the focus of this study on the manufacturing MSME sector, it is recommended that subsequent studies include large enterprises and other economic sectors and regions in Ghana. A replication of this study on a larger scale may be necessary to further substantiate low demand (explained by low incomes and low 
purchasing power) as a most relevant binding constraint to the ability of SMEs to access market. Moreover, studies on constraints facing Ghanaian SMEs that engage in export shall be necessary.

\section{References}

Abor, J., \& Quartey, P. (2010). Issues in SME development in Ghana and South Africa. International Research Journal of Finance and Economics, 39(2010), 218-228. Retrieved from: http://www.eurojournals.com/irjfe_39_15.pdf(February 10, 2011)

Annex: Summing Up by the Acting Chair. (2005). World Economic Outlook. Retrieved from: www.imf.org/external/pubs/ft/weo/2005/02/pdf/annex.pdf (May 4, 2007)

APEC. (2010). SME market access and internationalization: medium-sized term KPIs for the SMEWG strategic plan. Retrieved from: http://publications.apec.org/publication-detail.php?pub_id=1050

Appiah-Kubi, K. (2011). The Growing unemployment crisis in Ghana. Peace FM. Retrieved from: http://news.peacefmonline.com/features/201107/56933.php (February 9, 2012)

Aryeetey, E., \& Ahene, A. A. (2005). Changing regulatory environment for small-medium-sized size enterprises and their performance in Ghana. Retrieved from: http://www.competition-regulation.org.uk/conferences/southafrica04/AryeeteyAhene.pdf (October 3, 2011)

Aryeetey, E., \& Baah-Boateng, W. (2007). Growth, investment and employment in Ghana. Geneva: The International Labour Organisation.

Asche, H. (2006). The World Bank's Africa Action Plan: new actions? Bonn: Deutsches Institut für Entwicklungspolitik. German Development Institute GmbH.

Collier, P. (2007). The Bottom Billion. Oxford: Oxford University Press.

Confederation of Tanzania Industries. (2009). SMEs market access through private and public procurement and linkages. Retrieved from: http://www.esabmonetwork.org/fileadmin/esabmo_uploads/Tanzania_position_Paper_on_SME_Market_Ac cess_09.pdf(September 8, 2011)

Creswell, J. W. (1994). Research design: Qualitative and quantitative approaches. London: Sage Publications.

European Commission. (2010). Internationalisation of European SMEs: Final report. Brussels: European Union. Retrieved from: http://ec.europa.eu/enterprise/policies/sme/market-access/files/internationalisation_of_european_smes_final _en.pdf (September 2, 2011)

Hausmann, R., Rodrik, D., \& Velasco, A. (2006). Getting the diagnosis right: A new approach to economic reform. Finance \& Development, 43(1), 12-15.

IFC. (2010). Scaling-up SME access to financial services in the developing world. Paper presented at G20 Seoul Summit 2010. Retrieved from: http://www.ifc.org/ifcext/gfm.nsf/AttachmentsByTitle/G20SMEFinanceStocktaking/\$FILE/G20_Stocktakin g_Report.pdf (November 10, 2011)

Kayanula, D., \& Quartey, P. (2000). The policy environment for promoting small and medium-sized-sized enterprises in Ghana and Malawi. IDPM: University of Manchester.

Kufuor, A. A. (2008, June 19-21). Employment generation and small medium-sized enterprise (SME) development - the garment and textile manufacturing industry in Ghana. Paper presented at the International Forum on Sustainable Private Sector Development, Halifax, Canada. Retrieved from http://www.growinginclusivemarkets.org/media/publications/employment...(August 15, 2011)

Massey, C., Terry, A., Luwis, K., Perry, M., Walker, R., \& Warriner, V. (2005). Micro by name, medium-sized by nature? A report on an investigation into business excellence \& New Zealand. Wellington: New Zealand Centre for SME Research. from: www.massey.ac.nz/massey/fms/sme/.../Summary_Report_FINAL.pdf (December 5, 2011)

Mensah, M. S. B. (2012). Local business climate in Ghana - insights for policy direction. International Journal of Business and Management, 7(2), 17-35. http://dx.doi.org/10.5539/ijbm.v7n2p17

OECD. (2004, June 3-5). Facilitating SMEs Access to International Markets. Paper presented at the $2^{\text {nd }}$ OECD conference of ministers responsible for SMEs, Istanbul, Turkey. Retrieved from: http://www.oecd.org/dataoecd/6/12/31919223.pdf (August 12, 2011) 
The International Monetary Fund. (2007). World Economic and Financial Surveys. Regional Economic Outlook: Sub-Saharan Africa. Washington, D. C.: IMF. Retrieved from: http://www.imf.org/external/pubs/ft/reo/2007/afr/eng/sreo0407.pdf (June 29, 2007)

The International Monetary Fund. (2011). World Economic and Financial Surveys. Regional Economic Outlook: Sub-Saharan Africa. Washington, D. C.: IMF. Retrieved from: http://www.imf.org/external/pubs/ft/reo/2011/afr/eng/sreo1011.pdf (February 12, 2012)

UNCTAD. (2006). World Investment Report 2006. FDI from Developing and Transition Economies: Implications for Development. Switzerland: United Nations. Retrieved from: http://www.unctad.org/en/docs/wir2006_en.pdf (May 7, 2007)

UNIDO. (2006). Responsible trade and market access. Opportunities or obstacle for SMEs in developing countries. Vienna: UNIDO. [Online] Retrieved from: www.unido.org/.../user.../Responsible_trade_and_market_access.pdf (November 3, 2011)

Watson, J. (2003 Sept. 28-Oct. 1). SME performance: does gender matter? Paper presented at Small Enterprise Association of Australia and New Zealand $16^{\text {th }}$ Annual Conference, Ballarat. Retrieved from: www.cric.com.au/seaanz/resources/32WatsonDoesgendermatter.pdf (November 20, 2011)

WTO. (1999). Trade, income disparity and poverty. Switzerland: WTO. Retrieved from: www.wto.org/english/news_e/pres00_e/pov1_e.pdf (August 2, 2011) 